Old Dominion University

ODU Digital Commons

\title{
Understanding the Nature of Non-Profit Incubators with Other Sector Incubators in the Founding of Social Change Organisations by Social Entrepreneurs
}

\author{
Jesus N. Valero \\ Marina Saitgalina \\ Old Dominion University, msaitgal@odu.edu \\ Rachel A. Black
}

Follow this and additional works at: https://digitalcommons.odu.edu/publicservice_pubs

Part of the Entrepreneurial and Small Business Operations Commons, Nonprofit Administration and Management Commons, and the Technology and Innovation Commons

\section{Original Publication Citation}

Valero, J. N., Saitgalina, M., \& Black, R. A. (2021). Understanding the nature of non-profit incubators with other sector incubators in the founding of social change organisations by social entrepreneurs. Journal of Social Entrepreneurship. Advance online publication. 1-38. https://doi.org/10.1080/ 19420676.2021.1977975

This Article is brought to you for free and open access by the School of Public Service at ODU Digital Commons. It has been accepted for inclusion in School of Public Service Faculty Publications by an authorized administrator of ODU Digital Commons. For more information, please contact digitalcommons@odu.edu. 


\title{
Understanding the Nature of Nonprofit Incubators with other Sector Incubators in the Founding of Social Change Organizations by Social Entrepreneurs
}

\section{Jesus N. Valero}

University of Utah

jesus.valero@utah.edu

**Corresponding Author

\author{
Marina Saitgalina \\ Old Dominion University \\ msaitgal@odu.edu
}

Rachel A. Black

University of Utah

rachel.a.black@gmail.com

Word Count: 9202 


\title{
Understanding the Nature of Nonprofit Incubators with other Sector Incubators in the Founding of Social Change Organizations by Social Entrepreneurs
}

\begin{abstract}
Incubators have been studied extensively in the private sector, such as those that engage in technological innovation or growing small businesses. The scholarship has not sufficiently explored the efforts of incubators in the nonprofit sector that help create programs supporting, mentoring, and cultivating social entrepreneurs. There are numerous documented cases of nonprofit organizations establishing initiatives that help motivated entrepreneurs achieve social change; but research is lagging in developing a systematic understanding of these effort's impact, and the factors associated with the success of nonprofit initiatives that support social entrepreneurs. This paper seeks to understand the nature of nonprofit organizations that support and cultivate social entrepreneurs. We rely on a unique data set from survey research on nonprofit initiatives across three U.S. Census Regions. Results indicate that the characteristics of nonprofit organizations vary in their reliance on a variety of revenue resources and governance arrangements, as well as in their diverse policy focus. They also provide an extensive and diverse set of services that supports the ideas and efforts of social entrepreneurs.
\end{abstract}

Key words: Incubators, accelerators, nonprofit organizations, nonprofit incubators, social entrepreneurship. 


\section{Introduction}

Social change organizations are created to achieve socially desirable and lasting impacts on society and communities (Doherty, Haugh, and Lyon 2014). Thus, understanding the process by which social change organizations are created and the factors that lead to their success continue to be important areas of scholarly inquiry in the field of nonprofit organizations and management. To date, much of the literature on social change organizations tends to focus on their management and impact., with Lless attention is paid to how ideas are fostered and cultivated and the process that individuals or social entrepreneurs undertake to start a functioning and effective organization. Recent work has articulated the importance of studying the challenges and opportunities that social entrepreneurs face in their quest to create organizations that address social and community needs, which only helps inform theory and practice (Andersson 2017). Specifically, what process do social entrepreneurs undertake to materialize their social change ideas and create fully functional community organizations?

This study responds to this line of research by exploring the work of incubators that foster social change initiatives. Using existing literature on incubators as a baseline, ifncubators can be broadly defined as capacity building organizations that provide a continuum of services for entrepreneurs looking to bring an idea into fruition_(InBIA Operational Definitions 2017: Roundy 2017; Warren, Patton, and Bream 2009). As a legal entity, incubators can be organized as a private for-profit organization or as a nonprofit entity. As capacity building entities, they can play an important role in helping social entrepreneurs cultivate ideas and pursue the formation of an organization. Incubators have been studied extensively in the private sector such as those that engage in technological innovation ander growing small businesses (Aernoudt 2004; Clayton, Feldman, and Lowe 2018; Cohen 2013; Cohen, Fedher, Hockberg, and Murray 2019; Doherty, 
Haugh, and Lyon 2014; Hoffman and Radojevich-Kelley 2012; Patton 2014). For example, Patton (2014) studies the impact of university technology business incubators in building the capacity of new technology-based firms, and finds that collaboration between founders and other key stakeholders matters in explaining variation in capacity of new technology firms. In general, ; however, less attention has been paid to nonprofit incubators, particularly those focused on social change initiatives.

Incubators that focus on the support of social entrepreneurs is a relatively recent phenomenon (Sansone, Andreotti, Colombelli and Landoni 2020). In part, they evolved from business and technology incubators that emphasized social profitability outcomes impacting local development through job creation and tax base increase, as well as measures of social support of entrepreneurs through networking (Aernoudt 2004). And in part, the growth of social economy, hybridization of cross-sector organizations, and increasing complexity of social problems has spurred the surge of social incubators to support social ventures (Doherty, Haugh, and Lyon 2014; Ott and Dicke 2019; Pandey, Lall, Pandey, and Ahlawat 2017; Yang and Cheong 2019CITE). There are about 1,400 incubators in the U.S. alone and about 7,000 worldwide according to the International Business Innovation Association (InBIA 2016). Although the number of social incubators is not easily accessible, according to some countryspecific estimates, they constitute about $13 \%$ of incubators (Ogurtsov 2016).

What functions do nonprofit incubators engage in, and in what ways, if at all, are they different from other sector type incubators focused on social change efforts?

The impetus for this study was the exposure of the research team to the work of a university-supported nonprofit incubator in Salt Lake City, Utah. This incubator began to cultivate the ideas of community residents who were interested in starting new social change 
projects and organizations that addressed a dire need in their community. This effort was formalized in the creation of a start-up incubator that centralized support and provided space for community residents to meet, use computers, and access mentoring. The result of this incubation has been the creation of respected community organizations that are now working to build social capital for vulnerable populations, address necessary areas of social services, tackle complex social issues, and more. Similar efforts were noted by Custer (2015) in their case study of a university-based incubator in Flint, Michigan. The incubator made a concerted effort to attract and support a variety of community-driven ventures, including a nonprofit theatre company, a group that holds pitch competitions for community projects, and a veteran housing nonprofit. They were also recognized for connecting its participants to a broader local community ecosystem of entrepreneurs.

It is well established in the literature that complex social issues facing communities today require thinking outside the box, engaging cross-sector actors, and pursuing innovative policy solutions (Doherty, Haugh, and Lyon 2014). Social issues such as those related to poverty, homelessness, health, and the environment cannot be solved by a single organization, sector, or policy - thus, social change efforts may require the incubation of fresh and innovative ideas. Incubators with social change missions are an emerging phenomenon, but little is known about what they do and whether nonprofit incubators are different from other sector incubators in how they support entrepreneurs starting social change organizations.

More broadly, theoretically there is a gap in the knowledge about social change incubators (Sansone, et al. 2020). From the practice standpoint, given the growing significance of social incubators in fostering social entrepreneurship development and facilitation of local entrepreneurial eco-systems, understanding what they are and what they do can increase their 
exposure to support and funding needed for social investing. Further, understanding how they

operate and what makes them successful can produce the necessary knowledge for best practices

\section{to replicate and transfer their model to new markets (Galbraith, McAdam and Cross 2019).}

This study responds to this important yet understudied concept of incubators in the nonprofit sector by asking the following research questions: What is the nature of incubators that support entrepreneurs pursuing social change initiatives? In what ways are nonprofit incubators different from other sector type incubators? To answer these questions, this study relies on a descriptive study of incubators located in multiple regions of the US by using survey data collected in 2019. This paper is organized into four additional sections. First, we ground our inquiry in the concept of nascent entrepreneurship and review the literature on incubators by defining the concept and delineating the functions of incubators. In the next section, we present our research design, including context of the study and process of survey data collection. In the last sections, we present our findings and discuss future directions for research, including a research agenda to continue the exploration of incubators in the nonprofit sector.

\section{Literature Review}

\section{Nascent Entrepreneurship}

Creating a social change organization requires a process ranging from formulating an idea, securing financial resources, to the formation and delivery of programs and services. This preorganization phase of forming an entity is referred to in the literature as nascent entrepreneurship (Andersson 2017). As scholars have noted, the interest and research on the early stages of nonprofit organization is not new. Studies to date, for example, have focused on understanding the factors that explain the scale and scope of the nonprofit sector (Lecy and Slyke 2012), the characteristics of founders and their reasons for starting a new nonprofit organization (Carman 
and Nesbit 2012), and developing rich theoretical frameworks that explain the existence of the sector (Ott and Dicke 2019).

Andersson (2018) argues that the concept of nascent entrepreneurship is relevant to understanding and conceptualizing the important, but less understood, process by which individuals begin formulating and growing ideas into formal organizations that join the nonprofit sector. His work has found that entrepreneurs develop start-ups for instrumental and expressive reasons such as the desire to test new and unproven ideas, the need for income, and the interest in obtaining autonomy. Funding is generally expected from sources such as foundations, individual donations, donations from other organizations, personal income, and earned income (Andersson 2017). The mission of new start-ups also varies, with entities focusing on human service, followed by education, arts/culture, and health.

During the nascent phase, entrepreneurs are likely to also face a myriad of challenges including financial problems, information difficulties, and regulatory issues. Andersson (2019) found that financial and informational challenges have negative effects on start-up success, while regulatory problems have a positive effect. This means, for example, that entrepreneurs are less likely to be successful in launching their organization if they are unable to secure needed financial resources or lack the necessary information.

Hopp (2012) also explores the factors associated with the success of founding a new venture and specifically tests whether previous nonprofit experience matters. Results of their panel study suggests there is strong evidence for the value and importance of nonprofit experience in helping nascent entrepreneurs achieve success in establishing a new nonprofit organization. The results make sense: previous experience in the nonprofit sector translates into increased knowledge about their regulatory environment, funding sources that are needed and 
available, and perhaps the unique leadership and management needs of a nonprofit organization.

This acquired knowledge may pay dividends in securing needed resources and having the appropriate information to launch a new venture.

The results of these various studies on nascent entrepreneurship point to the dynamic processes of starting an organization, and the realities and challenges of conceiving an idea and taking the right steps to seeing those ideas to fruition into a legal, formal organization with a mission. Adequate funding sources, knowledge, experience, and support are all key factors for achieving a successful outcome. Incubators can play an important role in centralizing these supports in a one-stop-shop.

\section{Defining Incubators, Accelerators, and Other Related Terms}

There is ample research on technological incubators and start-ups, but fewer studies focused on those that are socially oriented - that either support or operate as nonprofit organizations. To understand our main research subject—incubators — we first focus on defining the term of incubators and other closely related concepts, and in table 1, we depict the overall similarities and differences between these concepts in Table 1.

According to the International Business Innovation Association (InBIA), incubators are support organizations that offer a variety of resources to start-up businesses for a fee. These resources may include office space, access to training and programs, and networking. Incubators usually have an application process and participation that is limited in time and requires performance achievements (InBIA Operational Definitions 2017).

Ahmad and Ingle (2011) defined campus incubators as organized "to support the creation and growth of its tenant firms during the start-up years through value-added contributions-the incubation process" (p. 628). Warren, Patton, and Bream (2009) defined incubators as focusing 
on providing professional resources, networking opportunities, and external assistance to organizations. Similarly, according to Yang and Cheong (2019), incubators assist with business processes such as fundraising, provide learning and training opportunities (such as how to build networks). Most studies agree that incubators facilitate and assist companies at the early stages to ensure their organizational success (Roundy 2017).

Accelerator is another concept in the literature that closely mirrors the effort of an incubator. The literature suggests that accelerators provide the same kind of services, such as office space, networking opportunities, business assistance, and training to start-up companies or on ad hoc basis (Hoffman and Radojevich-Kelley 2012; Roundy 2017). However, participation in accelerators can be limited in duration, often lasting no more than six months (Cohen, Fehder, Hochberg and Murray 2019), can be cohort-based (Roundy 2017), offers investor support in exchange for a stake of the participant equity (Cohen 2013), and concludes with an event where companies pitch their ideas (Hoffman and Radojevich-Kelley 2012).

Malek, Maine and McCarthy (2014) further differentiated between accelerators and incubators by suggesting that accelerators have a targeted focus in terms of time, resources, and connections, whereas incubators provide a wide range of support for start-ups. Mansoori, Karlsson and Lundqvist (2019) suggested that accelerators grew out of incubators as purposeful and specialized support venues that provide a more focused range of services than incubators.

When examining the differences between incubators, accelerators, and a third related concept - angel investors, Cohen (2013) found that accelerators focus exclusively on new ventures to help build up and launch their product, find investors or provide start-up funds, specify the niche market, and ensure other needed resources and business processes are in place for a successful venture. In her analysis of the existing disparities, Cohen (2013) also noted that 
accelerators are similar to incubators and angel investors, but not exactly the same. The similarity between accelerators and the other two initiatives is that accelerators target the initial stage of the start-up ventures, which might insinuate that many of the programs and resources offered by all three initiatives are the same. Nonetheless, the study presented accelerators to be unique in several ways, with the most significant ones being an intensive education and mentorship, structured selection process, and a time limited program participation in accelerators when compared to the on-going support and participant enrollment of incubators and angel investors.

Ahmad and Ingle (2011) further stressed the importance of building relationships in incubators. They found that there is no single program template that incubators follow, but rather, they build individual relationships with participants to be able to cater their services to specific needs. Therefore, successful participation in incubators would depend on the quality of a match between an incubator and a participating start-up.

Lastly, it is worth noting that coworking spaces have become a common arrangement in practice. InBIA defined coworking spaces as shared community space where individuals and organizations can rent a space for their work purposes via monthly memberships (InBIA Operational Definitions 2017). These spaces do not usually provide any other support aside from the workspace and do not engage in any performance-related activities. Given a somewhat ambiguous distinction between these various concepts (i.e., incubators, accelerators, etc), incubators have been used as an umbrella concept to describe platforms that support start-ups and their products (Komi et al. 2015). In this research we follow the same approach.

[insert Table 1 about here]

\section{Incubators' Roles and Impact}


To further examine the processes and performance of incubators, Messeghem et al. (2018) examined the various dimensions of nonprofit incubators' performance. The authors used a balanced scorecard approach for business incubators defined by Kaplan and Norton (2001) that includes financial, customer, internal business process, and learning and growth dimensions. When adapted to nonprofit incubators, these four dimensions were translated into local development performance, incubatee satisfaction, incubation processes, and learning. Each performance dimension was measured using several indicators. The authors then validated this instrument using a sample of nonprofit incubators in France and suggested that these four adapted dimensions were useful in assessing incubator performance in multidimensional form.

Other studies employed a case study approach to understanding accelerator's processes and roles in assisting start-up companies (Hoffman and Radojevich-Kelley, 2012). The authors found that accelerators benefit their participants in several ways. For example, accelerator participants have high rates of acquiring subsequent funding. They also report that they benefit from intensive mentorship that provide not only real-world knowledge but also a certain level of validation, since they would not be matched if their product or idea was not feasible to execute.

Research by Cohen et al. (2019) shows that the design of accelerators varies depending on the type of founders who sponsored the initiative and the background of founding managing directors. For example, government-sponsored accelerators founded by directors with public service backgrounds emphasized economic and regional development, while investor-led accelerators founded by former risk capital investors focus on the maximization of returns. Based on the design of the accelerator, its impact varied in the performance of their portfolio firms.

\section{Nonprofit Incubators and Social Change Initiatives}


While most previous literature studied incubators in general, in this study we are deliberate in seeking to understand the role and functions of nonprofit incubators specifically focused on social change efforts or supporting entrepreneurs who are interested in developing entities with a social change mission. Theoretically, nonprofit organizations share a few distinctive features, including the lack of coercion in participation, no distribution of profit to shareholders, and missions that are community-and charity-driven (Ott and Dicke 2019). We anticipate that incubators of the nonprofit form will then share some of these features in how they are structured, in the sources of funding they rely on, and the types of policy initiatives they pursue through their support of social entrepreneurs. Some apparent differences between nonprofit and for-profit entities include their legal status and their ultimate focus (profit-making versus community focus). For example, in their incorporation process in the U.S., organizations must choose whether they will be organized as a for-profit organization or as a nonprofit organization. Nonprofit organizations are not allowed to distribute profits to any member of the organizations and are expected to be community-driven and focused. Thus, we anticipate that differences may exist in how nonprofit incubators are organized and the kind of work they do when compared to for-profit incubators.

Among the few studies that we found that focused specifically on nonprofit incubators, the overall conclusion was that it is hard to delimit them from traditional incubators based on the kind of services and programs they offer (Peters, Rice, and Sundararajan 2004; Pandey et al. 2017; Messeghem et al. 2018; Custer 2015; Yang and Cheong 2019). For example, Custer (2015) noted that the socially oriented incubator in their case study supported both business and commercial ventures as well as provided support, coaching and mentorship to students' entrepreneurial ideas. 
Among some differences, Peters, Rice, and Sundararajan (2004) found that the number of graduates were the highest in nonprofit incubators when compared to for-profit or university incubators. The presence or absence of coaching and access to networks impacted the graduation rate. Specifically, they suggested that the knowledge resources possessed by those networks distinguished the different types of incubators. However, the data, interviews and their models could not provide strong explanation, so the authors concluded that a more comprehensive model is required to explain the impact of incubators on the entrepreneurial process.

Messeghem et al. (2018) also stressed the importance of paying attention to the value that participants place on services and programs offered by incubators, when studying nonprofit incubators in France. They further emphasized the value of connecting participants to networks and helping them manage these connections. Finally, the authors noted the significance of organizational learning and funding diversification (acquiring different forms of capital).

In their study of an NGO incubator in China, Yang and Cheong (2019) highlighted their network-spanning role. The authors emphasized a unique ability of the entity to facilitate relationships among different actors in a wider civil society ecosystem with government, forprofit, and nonprofit partners. The incubator positioned itself in the network structure as a broker that created opportunities for diverse collaborations and relationship building.

Pandey et al. (2017) noted further differences when they asked social entrepreneurs about the value of social accelerators. First, support of social ventures is expected to take longer when compared to technological start-ups. Social issues are more complex, which may assume more intense and prolonged support of organizations with social goals. Further, the processes themselves may vary for a social start-up to be launched when combining social and commercial goals. For example, the authors suggested that services and programs offered to social ventures 
will be valued by them differently based on their knowledge and experience. For example, they found that organizations with no prior experience valued mentorship, and those with experience valued funding resources. Networking and business training were least valued by both groups. Therefore, the authors suggested to focus on the fit between social incubators and accelerators and their participants.

These diverse perspectives on the role and impact of nonprofit incubators still leave us with the following questions: What is the nature of incubators that support entrepreneurs pursuing social change initiatives? And in what ways are nonprofit incubators different from other sector type incubators?

\section{Methods}

\section{Data}

To answer our research questions, we rely on a 2019 survey of incubators operating in select regions of the U.S. In order to identify our sample, we adopted the following sampling frame. First, we decided to focus on three U.S. Census regions as members of our research team were centrally located in these areas. These regions included: Western, South Atlantic, and Northeast. A total of $31^{1}$ states comprise these regions, constituting a significant proportion of the U.S. Second, because of our interest in understanding incubators that support social change efforts as opposed to business or technological development, we narrowed our search of incubators to those specifically focused on social change initiatives. Third, based on our review of the literature, we understood that incubators could exist in cross sector spaces including private, nonprofit and university sectors. Thus, we decided to include incubators focused on social

\footnotetext{
${ }^{1}$ Western Region: Arizona, Colorado, Idaho, New Mexico, Montana, Utah, Nevada, Wyoming, Alaska, California, Hawaii, Oregon, and Washington; South Atlantic Region: Delaware, District of Columbia, Florida, Georgia, Maryland, North Carolina, South Carolina, Virginia, and West Virginia; Northeast Region: Connecticut, Maine, Massachusetts, New Hampshire, Rhode Island, Vermont, New Jersey, New York, and Pennsylvania.
} 
change missions regardless of the sector orientation. This then would allow us to engage in comparative analysis of nonprofit incubators versus those in the private sector. Lastly, based on our review of literature, incubator, accelerator, and coworking spaces may be used interchangeably and with little difference across them in practice — we accordingly opted to include all three types of spaces in our identification of our survey sample.

Using these set of criteria, we conducted a structured online search using Google and identified a total of 506 organizations. From these searches, we collected the key contact information including email address and phone number of the organization's leader or executive director and available documents to understand the work and efforts of the organization. A total of 506 surveys were deployed to these contacts and 117 survey responses received - for an overall response rate of $23 \%$.

\section{Survey}

An online survey was developed in Qualtrics to assess the characteristics of incubators across the U.S. The survey contained a total of 48 questions divided into four sections, including: information about the organization, about the start-up initiative, outcomes, and demographics. These questions were informed by previous research on incubators and the variety of activities they tend to engage in through the incubation process. In addition, we piloted the survey with a few select organizations and sought to receive feedback on the content and structure of the survey. Based on the feedback received, we further refined and restructured our survey to ensure that we were speaking the language of these type of entities and that we asked each question clearly. Data collected from sections 1, 2, and 3 were used to address our first research question focused on the nature of incubators as well as the second research question on the differences of nonprofit incubators when compared to for-profit incubators. 
The first section of the survey focused on the organization in general. This section asked whether the respondent organization was a nonprofit, university or other type of sector organization, the number of years in operation, type of governance used, its annual budget, and number of employees.

The second section obtained information on the specific services provided, number of participants, what social policy issues they were addressing, the average length of time participants stayed with the organization, and other similar questions. Sample questions that formed a part of this section included:

- How many years has your start-up initiative been in existence?

- Does your start-up initiative have a focus on any of the following policy issues?

- Which of the following reasons led to the creation of your start-up initiative?

The third section focused on the outcomes such as success in supporting participants, success in meeting program goals, and contributions to their community. Through these dimensions, we sought to identify various levels of analysis: individual, organizational, and the community level. This is consistent with previous research and practice on measuring outcomes of any kind of initiative at multiple levels of analysis. Sample questions included in this section are:

- In the last three years, to what extent has your start-up initiative been able to achieve success in supporting start-up participants in the following areas?

- In the last three years, to what extent has your start-up initiative been able to achieve success as a program in the following areas?

- In the last three years, to what extent has your start-up initiative been able to contribute value to the community it serves in the following areas? 
The final section asked about the respondents' experience with the start-up organization, their age, gender, race and ethnicity, and education. Ultimately, the survey was launched in the Spring of 2019.

\section{Analysis}

Given the exploratory nature of this study we conduct a descriptive analysis of our survey data to answer our first research question: What is the nature of incubators that support entrepreneurs pursuing social change initiatives? (see for example, Jang, Valero, and Jeong 2020). To answer our second research question (in what ways are nonprofit incubators different from other sector type incubators?), we conduct a means analysis using ANOVA analysis for continuous variables and Crosstab analysis for categorical variables to compare two groups of our survey incubators that are self-identified as nonprofit organizations and incubators in other categories (i.e., private for-profit or university). ANOVA and Crosstab analyses were used based on the parameters of our data (continuous and categorical) and the research questioncomparison across groups (Nishishiba, Jones, and Kraner 2014).

For the means analysis, we included the following variables: years of operation, budget, number of full-time and part-time employees, number of their start-up program years, number of start-up participants, the degree to which incubator relies on diverse revenue resources, and the number of services offered by incubator (financial, leadership, communication, and legal). For the Crosstab analysis, the selection of variables included governance structure, whether incubator relies on volunteers, whether any particular logic model is the basis of incubator's work, whether incubator is a member of a network of other incubators, the designation of their start-up initiative, geography of service, policy focus, and reasons that led to the creation of the incubator. 


\section{Results}

The results yielded interesting findings with regards to the work of incubators. For our first research question, we explored the nature of the incubators, including their varieties, years in operation, budget, and governance structure, among other descriptive indicators.

As noted in table 2, about half of respondents identified their incubator as a nonprofit organization (52\%), whereas incubators that are affiliated with a university accounted for $26 \%$ of survey respondents. About $10 \%$ of incubators were self-identified as belonging to the private, for-profit sector and a remaining $10 \%$ identified as other. The other category included incubators that self-identified as hybrid forms such as social enterprises and business organizations within a university system, county governments, and public-private partnership. Incubators also vary in age or the number of years that the organization has been in operation. About a third of respondents are relatively new-38\% have been in operation for less than 9 years. But the vast majority $(62 \%)$ have been in operation for $10+$ years.

\section{[Table 2 about here]}

Table 2 also provides the results on the governance structure of incubators. Considering the variety of sector type incubators in our sample, specifically the number that are nonprofit organizations, it is no surprise that a majority of respondents have a board of directors (38\%). About $22 \%$ of respondents note that they govern their organization through a management team - perhaps pointing to a level of professionalism and capacity. A fewer number of incubators report having an advisory board (15\%) and university appointee (5\%). The other category included mixed responses such as a governance structure involving a board selected by county government, a president/CEO, and county citizens, among others. 
Survey respondents were also asked to provide details on the size of their budget and the variety of sources from which they collect revenues. Incubator budgets range from zero revenue or as little as $\$ 2,000$ to $\$ 70$ million - with a mode of $\$ 300,000$, median of $\$ 392,500$, and an average of $\$ 3.3$ million. Respondents were also asked to identify the variety of revenue sources on which they rely. The largest categories of revenue are government grants (22\%), fees (17\%), rent (13\%), other (12\%), university support (8\%), contracts (9\%), and foundation grants (9\%). The percentage in parenthesis indicates the average portion of the revenue source, whereas the count in table 2 indicates how many respondents chose that category as one of their revenue sources.

While a focus of this research is to understand incubators supporting broadly defined social change initiatives, we are interested in further exploring the specific policy focus of incubators. As noted in table 2, out of a list of nine pre-identified policy issues such as children's issues, workforce development, and education, respondents were asked to identify the different policy issues they specialized in. The top five policy priorities were technology development (18\%), followed by education (13\%), health (12\%), workforce development (12\%), and women's issues $(11 \%)$.

To understand the differences between nonprofit incubators and other sector incubators (Research Question 2), we conduct a series of crosstabulation and ANOVA analyses to compare key variables of interests. Table 3 reports the ANOVA results. Out of the eleven variables included in the analysis, five resulted in statistically significant differences between the two groups: years of operation, budget, number of full-time employees, revenue diversity, and number of communication services. In terms of years of operation, it appears that nonprofit incubators in our sample, on average, are about 10 years older than other sector incubators. The 
budget of nonprofit incubators, on average, is significantly larger when compared to other sector incubators in our sample. We further conduct an outlier analysis which showed that there are two significant outliers with values more than three standard deviations above the mean. When these two outliers are omitted, the budget difference between the two groups loses its statistical significance $(p$-value $=.241)$. Number of full-time staff was also significantly different with nonprofit incubators, on average, having more employees than other sector incubators.

With regards to revenue diversity, respondents were asked to report the variety of sources that they rely on for revenue and to select out of a possible 10 different sources including: rent, fees, contracts, foundation grants, government grants, private donations, special events, university support, and an option for two different "other" categories. Results indicate that nonprofit incubators rely on an average of 2.7 revenue sources compared to 1.9 different revenue resources for other sector type incubators and this relationship was statistically significant ( $p$ value $=0.082$ ). This suggests that nonprofit incubators seek to diversify their sources much more than incubators that are either private, for-profit or university incubators.

Finally, survey respondents were also asked to report the variety of services that they provide to incubator participants. These various services were categorized as either financial, leadership, communication, or legal. The number of communication services that nonprofit incubators provide, on average, was statistically significantly bigger than that of other sector incubators. Out of a possible list of 19 communication services, nonprofit incubators on average provide 16.1 services compared to 12.5 services provided by other sector incubators ( $p$-value $=$

[Table 3 about here] 
Table 4 reports the results of Crosstabulation analysis for categorical variables. In terms of governance structure, statistically significantly more nonprofit incubators have a board of directors than other sector incubators $(p$-value $=.000)$. Other governance structures were similarly represented in both groups. The use of volunteers, the use of a logic model, and network member affiliations did not differ significantly between the groups. In terms of the designation of their start-up initiative, significantly more nonprofit organizations chose incubator $(p$-value $=.087)$ and "other" category $(p$-value $=.030)$ as their designation, which included hybrid forms and sites to conduct workshops for start-ups. When asked about the geography of service, nonprofit incubators were significantly more involved at the state level ( $p$-value $=.007$ ). Nonprofit incubators were also significantly more likely to serve the "other" geographical category compared to other sector incubators $(p$-value $=.060)$. This category for nonprofit incubators included regions not confined to administrative jurisdictions, instead describing their geography of service as rural areas, or having national or international focus.

In terms of policy focus, there are some notable differences between nonprofit and all other incubators. Specifically, more nonprofit incubators than other incubators focused their efforts on education $(p$-value $=.006)$, health $(p$-value $=.015)$, workforce development $(p$-value $=$ $.000)$, women's issues $(p$-value $=.016)$, social justice $(p$-value $=.003)$, children's issues $(p$-value $=.012)$, and the other category $(p$-value $=.005)$. The "other" policy focus category included environment, nutrition, and rural development. Nonprofit and all other incubators were no different in most "reasons for creation" and only varied in one reason, which is community demand or need $(p$-value $=.003)$. Significantly more nonprofit incubators were created because of the community need when compared to the other sector incubators.

[Table 4 about here] 


\section{Discussion}

We began this research with an interest in understanding the work of incubators in supporting entrepreneurs with an interest in founding social change initiatives and whether there were differences between incubators of the nonprofit form versus other sector types such as private, for-profit incubators and incubators associated with universities. We specifically sought to answer two research questions: What is the nature of incubators that support entrepreneurs pursuing social change initiatives? In what ways are nonprofit incubators different from other sector type incubators?

With regards to their objective characteristics, about half of our sample belong to the nonprofit sector, two thirds have been founded less than 20 years ago, and more than a third uses board of directors' governance structure. For example, based on the age categories included in our survey, most incubators tend to be younger organizations — suggesting that the incubator form tends to be a recent phenomenon for at least some communities represented in our survey sample. Incubators also tend to rely on common governance arrangements, particularly those common within nonprofit organizations - namely, a board of directors and management team. Considering the nature of incubators, we found that incubators in our sample of respondents tend to focus on a variety of social change policy areas from education to workforce development to health to technology development. The last of these — technology development — was found to be most prevalent followed by education, health, and workforce development. This result indicates that at least in this sample of social change efforts, the focus extends beyond tech development as predominantly found in the private-for profit literature, with incubators in this sample also paying attention to other important policy arenas. Thus, the policy focus of social change 
incubators tends to be diverse. Two thirds of our respondents who selected technology

development as their focus also selected other areas of focus alongside it.

Overall, the picture that emerges of incubators in our U.S. sample is that there is extensive diversity in the nature of these entities that support social entrepreneurs. They vary in the sector orientation (nonprofit vs. other) as well as in other substantive characteristics including their reliance on a variety of revenue resources and governance arrangements as well as in their diverse policy focus. These results further align with previous work challenged in identifying unique descriptors of these incubator initiatives.

Our second research question placed a focus on assessing differences between nonprofit incubators and incubators of other sector types, such as for-profit and university incubators. Our results indicate that indeed differences exist in the explored factors, including the type of services offered and the diversity of revenue resources that incubators depend on. Specifically, nonprofit incubators tend to seek out more diverse revenue resources when compared to other sector types. This finding is consistent with previous work on revenue diversification and the importance of this practice for nonprofit sustainability (Doherty, Haugh, and Lyon 2014). Nonprofit status further enables incubators to be eligible for federal and foundations' grants that would not be accessible to their for-profit counterparts (Clayton, Feldman, and Lowe 2018). Previous research has also found that nascent entrepreneurs tend to expect diverse funding resources to start their nonprofit organization (Andersson 2018). Alternatively, the findings of this research suggest that incubators may also rely on multiple sources of revenue in the absence of a single funder or funding type available for these types of effortsincubators to pursue multiple revenue sources to sustain their initiatives. 
Interestingly, nonprofit incubators also tend to offer more services to start-up participants than other sector organizations. While not tested in this research, we suspect that this may be due to an increasing capacity of nonprofit incubators resulting from the diversity of revenue resources. Alternatively, the explanation may lie with the diverse range of incubator participants. Nonprofit incubators may have a much more diverse profile of participants, which results in more varied service requests that need accommodation. Specifically, nonprofit incubators tend to offer more financial, leadership, legal, and communication services when compared to other incubator types - with the difference in communication services being statistically significant.

Previous literature pointed to some of the evidence in support of our findings. For example, Peters, Rice, and Sundararajan (2004) found that in their sample nonprofit incubators had the highest number of graduates when compared to for-profit and university-based incubators, which indirectly supports our assumption for higher demand of diverse services among more participants. Yang and Cheong (2019) pointed to NGO incubators' role in building and strengthening networks and alliances across different sector' participants in China, which may also result in a diverse pool of participants with varied needs.

Our results also indicate that nonprofit incubators tend to differ from other sector incubators based on their geography of service, policy focus, and reasons for creation. We were intrigued by the finding that nonprofit incubators tend to serve geographies at the state and other levels and often focused on key social change policy initiatives when compared to other sector organizations, including a focus on education, children, women, and health. Since nonprofit organizations are mission-driven they support entrepreneurs with a variety of public issue focuses. This may also be reflected in the broader geographic coverage. Lewis, HarperAnderson, and Molnar (2011) found that top performing incubators focus, among other things, 
on promoting entrepreneurial ecosystems, which would translate into the diversity of resources, services, participants, and geography that our sample represented. Additionally, nonprofit incubators were more likely than other sector incubators to be developed as a response to community need — suggesting that other sector incubators may be created for reasons not necessarily rooted in community needs or challenges.

Once again, diversity emerges as the theme in nonprofit incubators: diversity of funding, services, and geography of service. Since over half are structured as nonprofit organizations themselves, they are likely following the best practice, and arguably the necessity of the day, with diversification of funds in order to prevent organizational and financial crisis in the event of lost revenue. The diversity of services may arise in part from conditions imposed by various funding sources, or alternatively, they may be made possible by them. The limited number and specialization of nonprofit incubators in each state may lead to the necessity of social change organizations participating over larger geographic distances; thus, explaining the diverse geography of services especially for rural organizations.

In general, our finding that nonprofit incubators are different from other sector incubators is interesting and contrary to previous work that has suggested that it is hard to distinguish between sector orientation of incubators (Pandey et al. 2017; Messeghem et al. 2018; Custer 2015; Yang and Cheong 2019). Our results indicate that there are substantive differences between-nonprofit incubators and differ those from the private or other sectors- based on the type of services offered, diversity of revenue resources, geography of service, policy focus, and $\underline{\text { reasons for creation. }}$

\section{Conclusion}


We began this study with the goal of understanding the nature of incubators that support social

Formatted: Indent: First line: 0" change initiatives and whether differences exist between nonprofit incubators and those of other sector orientations (i.e., private and university sectors). We found that incubators in general range in the type of services they offer, revenues they rely on, and the structures they use to govern their affairs, and that nonprofit incubators are indeed different from other sector incubators in key dimensions such as the type of services they offer, the policy focus of their efforts and training, and in the geographies they serve - among others. In conclusion, Tthis $\underline{\text { research contributes }} \underline{\text { to the empirical evidence to yet scant literature on social incubators, their }}$ nature and unique features that differentiate them from other type of incubators. Our findings classify social incubators differently based on the type of services offered, diversity of revenue resources, geography of service, policy focus, and reasons for creation, which collectively paints a picture of the nature of these relatively new entities in the entrepreneurial ecosystem.

-Our research findings have key implications for both theory and practice.

From a practical perspective, this study sheds light on the nature of incubators, their specific organizational structures and the policy areas they tend to focus on. Results also offer possible best practices for entities looking to understand how to govern and structure their efforts. For example, our results indicate that a sizable majority has a board of directors and a management team - similar to the typical nonprofit organization. This can be used to inform how old and new incubators may decide to organize, or reorganize, their entity to enjoy this established model's benefits These benefits include an active management team that can work directly with social change organizations and assess their needs., Meanwhile the board takes the responsibility of fundraising and providing oversight, motivated by ethical and legal obligations. Lastly, this research presents important differences between nonprofit incubators and the other 
sector types we surveyed, which can be used to understand the functions and efforts of nonprofit incubators within local communities.

From a research perspective, this study offers insights into an area of work that is understudied in the nonprofit management literature. Nonprofit incubators are an emerging phenomenon, and they present a worthwhile laboratory to empirically explore innovative efforts to affect social change. Future work should analyse the impact of nonprofit incubators on the social economy of the community they serve as well as study the factors that condition some incubators to be more successful than others. Likewise, studies to assess whether commonalities exist among services that correlate with success among nascent social change organizations could guide nonprofit incubators in their choice of services. Because of their innovativeness, it will be interesting to observe whether incubators are working in silos or in cooperation and collaboration with other cross-sector actors in their delivery of services to nascent entrepreneurs. This work also brings attention to the use of technology in social change initiative service delivery and contributes to the growing, important literature on nascent entrepreneurship which attempts to explore the incubators work to develop and incubate social change ideas within local communities.

Despite these key contributions to research and practice, our work faces some limitations. First, we use only a sample of U.S. regions and our response rate was lower than hoped for, thus our results are not necessarily generalizable to all areas across the U.S. We believe that future research should consider exploring other regions to assess whether meaningful differences exist and whether some regions may place greater emphasis on certain policy issues or have different structures. Second, we rely on a structured survey and we are left with curiosities about choice of sector orientation and why some incubators are necessarily organized as nonprofit organizations 
versus other sector arenas. In-depth interviews and other forms of data collection may offer greater insight into the rationale for organizing and incorporating as nonprofit organizations and the advantages that founders find in creating a nonprofit incubator versus a different sector orientation._Lastly, our work does not consider the impact that nonprofit incubators have versus other types of sector incubators. Future research should explore whether being a nonprofit incubator materializes in meaningful ways by having a greater impact in achieving change within the communities they serve.

In conclusion, this research contributes the empirical evidence to yet scant literature on social incubators, their nature and unique features that differentiate them from other type of ineubators. Our findings classify social incubators differently based on the typeof services effered, diversity of revenue resolrces, geography of service, poliey focus, and reasens for ereation, which collectively paints a picture of the nature of these relatively new entities in the entrepreneurial ecosystem. 


\section{References}

Aernoudt, Rudy. 2004. “Incubators: Tools for Entrepreneurship?” Small Business Economics, 23 (2)" $127-135$.

Ahmad, Ali J., and Sarah Ingle. 2011. "Relationships Matter: Case Study of a University Campus Incubator.” International Journal of Entrepreneurial Behaviour and Research 17 (6): 626-644. doi:10.1108/13552551111174701

Andersson, Fredrik O. 2017. “A New Focus on Nonprofit Entrepreneurship Research: Highlighting the Need and Relevance of Nascent Stage Inquiry.” Nonprofit Management and Leadership 28 (2): 249-58. doi: https://doi.org/10.1002/nml.21271

Andersson, Fredrik O. 2018. "Start-up Funding Intentions Among Nascent Nonprofit Entrepreneurs: An Exploratory Investigation.” Journal of Public and Nonprofit Affairs 4 (1): 7-20. doi: https://doi.org/10.20899/jpna.4.1.7-20

Andersson, Fredrik O. 2019. "The Bumpy Road of Nonprofit Creation: An Examination of StartUp Problems Encountered by Nonprofit Entrepreneurs.” Nonprofit and Voluntary Sector Quarterly 48 (1): 194-207. doi: https://doi.org/10.1177/0899764018785464

Carman, Joanne G. and Rebecca Nesbit. 2012. "Founding New Nonprofit Organizations:

Syndrome or Symptom?" Nonprofit and Voluntary Sector Quarterly 42 (3): 603-21. doi: https://doi.org/10.1177/0899764012459255

Clayton, Paige, Maryann Feldman, and Nichola Lowe. 2018 "Behind the Scenes: Intermediary Organizations that Facilitate Science Commercialization through Entrepreneurship.” Academy of Management Perspectives 32 (1): 104-124.

https://doi.org/10.5465/amp.2016.0133 
Cohen, Susan. 2013. "What do Accelerators do? Insights from Incubators and Angels." Innovations: Technology, Governance, Globalization 8 (3-4): 19-25.

Cohen, Susan, Daniel C. Fehder, Yale V. Hochberg, and Fiona Murray. 2019. "The Design of Startup Accelerators.” Research Policy 48 (7): 1781-1797. doi: https://doi.org/10.1016/j.respol.2019.04.003

Custer, Nic. 2015. "IN Like Flint: How the Innovation Incubator at UM-Flint Fosters Social Entrepreneurship in a City Remaking Itself.” Metropolitan Universities 26 (1): 53-70.

Dart, Ray, Olakunle Akingbola, and Katie Allen. 2019. "Nonprofit Adaptation and Variation in Changing Contexts: The Speciation of Shared Platform Organizations." Canadian Journal of Nonprofit and Social Economy Research 10 (1): 26-40. doi: https://doi.org/10.22230/cjnser.2019v10n1a282

Doherty, Bob, Helen Haugh, and Fergus Lyon. 2014. "Social Enterprises as Hybrid Organizations: A Review and Research Agenda.” International Journal of Management Reviews 16 (4): 417-436. doi: https://doi.org/10.1111/ijmr.12028

Galbraith, Brendan, Rodney McAdam, and Stephen Edward Cross. 2019 "The evolution of the incubator: past, present, and future." IEEE Transactions on Engineering Management 68,

\section{(1): 265-271.}

Hoffman, David L. and Nina Radojevich-Kelley. 2012. “Analysis of Accelerator Companies: An Exploratory Case Study of their Programs, Processes, and Early Results.” Small Business Institute Journal 8 (2): 54-70.

Hopp, Christian. 2012. "For Better or for Worse? - Nonprofit Experience and the Performance of Nascent Entrepreneurs.” Nonprofit and Voluntary Sector Quarterly 41 (6): 1251-1268. doi: https://doi.org/10.1177/0899764012449517 
InBIA. 2016. Number of US Entrepreneurship Centers by Type. Retrieved from https://inbia.org/wp-content/uploads/2018/08/NumberofECsimage.jpg?x62369

InBIA. 2017. Operational Definitions: Entrepreneurship Centers (Incubators, Accelerators, Coworking Spaces and Other Entrepreneurial Support Organizations). Retrieved from https://inbia.org/wp-content/uploads/2016/09/Terms_4.pdf?x62369

Jang, Hee Soun, Jesus N. Valero, and Jihoon Jeong. 2020. “A Study of Cross-Sector Health Care Services for the Homeless: Community Health Service Capacity Measured and Tested.” Journal of Health and Human Services Administration 43 (2): 178-195.

Komi, Marjaana, Kaisa Still, Arto Wallin, and Päivi Jaring. 2015. “Accelerating the Innovation Process of Start-ups-Business Incubator and Accelerator Services in Finland.” The International Society for Professional Innovation Management (ISPIM) Conference Proceedings 1-14. Retrieved from https://cris.vtt.fi/en/publications/accelerating-theinnovation-process-of-start-ups

Lecy, Jesse D. and David M. Van Slyke. 2012. "Nonprofit Sector Growth and Density: Testing Theories of Government Support." Journal of Public Administration Research and Theory 23 (1): 189-214. doi: https://doi.org/10.1093/jopart/mus010

Lewis, David A., Elsie Harper-Anderson, and Lawrence A. Molnar. 2011. “Incubating success. Incubation best practices that lead to successful new ventures." Ann Arbor: Institute for Research on Labor, Employment, and Development.

Malek, Kourosh, Elicia Maine, and Ian P. McCarthy. 2014. “A Typology of Clean Technology Commercialization Accelerators." Journal of Engineering and Technology Management, 32: 26-39. doi: https://doi.org/10.1016/j.jengtecman.2013.10.006 
Mansoori, Yashar, Tomas Karlsson, and Mats Lundqvist. 2019. "The Influence of the Lean Startup Methodology on Entrepreneur-Coach Relationships in the Context of a Startup Accelerator." Technovation 84-85: 37-47. doi:

https://doi.org/10.1016/j.technovation.2019.03.001

Messeghem, Karim, Chaffik Bakkali, Sylvie Sammut, and Abdelaziz Swalhi. 2018. "Measuring Nonprofit Incubator Performance: Toward an Adapted Balanced Scorecard Approach.” Journal of Small Business Management 56 (4): 658-680.

Nishishiba, Masami, Matthew Jones, and Mariah Kraner. 2014. "Comparing Means of more than Two Groups: Analysis of Variance (ANOVA)." In Research Methods and Statistics for Public and Nonprofit Administrators: A Practical Guide (pp. 193-221). SAGE

Publications, Inc., https://www.doi.org/10.4135/9781544307763

$\underline{\text { Ogurtsov, Evgeny S., Andrey A. Rylov, Dzhennet A. Durdyeva, Nikita A. Lebedev, Karine S. }}$

Khachaturyan, Arman M. Safyan, Konstantin V. Rochev, and Guzal R. Tsareva. 2016.

"The role of business incubators in supporting economic growth and advancement of small business of the Russian Federation." Indian Journal of Science and Technology 9 (29): 1-6. DOI: $10.17485 / \mathrm{ijst} / 2016 / \mathrm{v} 9 \mathrm{i} 29 / 89339$

Ott, J. Steven, and Lisa A. Dicke, eds. 2019. Understanding Nonprofit Organizations:

Governance, Leadership, and Management $3^{\text {rd }}$ ed. Westview Press: Boulder, CO.

Pandey, Sheela, Saurabh Lall, Sanjay K. Pandey, and Sucheta Ahlawat. 2017. "The Appeal of Social Accelerators: What do Social Entrepreneurs Value?" Journal of Social Entrepreneurship 8 (1): 88-109. doi: https://doi.org/10.1080/19420676.2017.1299035 
Patton, Dean. 2014. "Realising potential: The impact of business incubation on the absorptive capacity of new technology-based firms." International Small Business Journal 32(8): 897-917. https://doi.org/10.1177/0266242613482134

Peters, Lois, Mark Rice, and Malavika Sundararajan. 2004. “The Role of Incubators in the Entrepreneurial Process.” The Journal of Technology Transfer 29 (1): 83-91. doi:10.1023/B:JOTT.0000011182.82350.df

Roundy, Philip T. 2017. "Hybrid Organizations and the Logics of Entrepreneurial Ecosystems." International Entrepreneurship and Management Journal 13 (4): 1221-1237. doi:10.1007/s11365-017-0452-9

$\underline{\text { Sansone, Giuliano, Pietro Andreotti, Alessandra Colombelli, and Paolo Landoni. 2020. "Are }}$ $\underline{\text { social incubators different from other incubators? Evidence from Italy." Technological }}$

Forecasting and Social Change 158:120-132. https://doi.org/10.1016/j.techfore.2020.120132

Warren, Lorraine, Dean Patton, and David Bream. 2009. "Knowledge Acquisition Processes during the Incubation of New High Technology Firms," International Entrepreneurship and Management Journal 5 (4): 481-495. doi: 10.1007/s11365-009-0121-8

Yang, Aimei and Hope Cheong. 2019. "Building a Cross-Sectoral Interorganizational Network to Advance Nonprofits: NGO Incubators as Relationship Brokers in China.” Nonprofit and Voluntary Sector Quarterly 48 (4): 784-813. doi:

https://doi.org/10.1177/0899764018819869 
Table 1: Matrix of Similarities and Differences Between Incubators, Accelerators, \& Coworking Spaces

\begin{tabular}{l|c|c|c|c|c|c} 
& $\begin{array}{c}\text { Physical } \\
\text { Space }\end{array}$ & $\begin{array}{c}\text { Training \& } \\
\text { Programs }\end{array}$ & Networking & $\begin{array}{c}\text { Time } \\
\text { Limited } \\
\text { Support }\end{array}$ & $\begin{array}{c}\text { Cohort- } \\
\text { Based }\end{array}$ & $\begin{array}{c}\text { Investor } \\
\text { Support in } \\
\text { Exchange } \\
\text { for Equity }\end{array}$ \\
\hline Incubators & $\mathrm{X}$ & $\mathrm{X}$ & $\mathrm{X}$ & & & \\
\hline Accelerators & $\mathrm{X}$ & $\mathrm{X}$ & $\mathrm{X}$ & $\mathrm{X}$ & $\mathrm{X}$ & $\mathrm{X}$ \\
\hline $\begin{array}{l}\text { Coworking } \\
\text { Spaces }\end{array}$ & $\mathrm{X}$ & & & & & \\
\end{tabular}


Table 2. Descriptive Indicators of Incubators

\begin{tabular}{|c|c|c|}
\hline Descriptors & Percent & Count \\
\hline \multicolumn{3}{|l|}{ Sector Type } \\
\hline We are a nonprofit organization & $52 \%$ & 35 \\
\hline We are a division, department, or program of a university & $27 \%$ & 18 \\
\hline We are a private, for-profit organization & $10 \%$ & 7 \\
\hline Other & $10 \%$ & 7 \\
\hline \multicolumn{3}{|l|}{ Age } \\
\hline $1-9$ years & $38 \%$ & 24 \\
\hline $10-19$ years & $28 \%$ & 18 \\
\hline 20-29 years & $9 \%$ & 6 \\
\hline more than 30 years & $25 \%$ & 16 \\
\hline \multicolumn{3}{|l|}{ Governance Structure } \\
\hline Advisory Board & $15 \%$ & 11 \\
\hline Board of Directors & $38 \%$ & 27 \\
\hline Consultant & $0 \%$ & 0 \\
\hline Management team & $22 \%$ & 16 \\
\hline Steering committee & $0 \%$ & 0 \\
\hline University Appointee & $5 \%$ & 4 \\
\hline Other & $19 \%$ & 14 \\
\hline \multicolumn{3}{|l|}{ Budget } \\
\hline Under $\$ 250,000$ & $33 \%$ & 18 \\
\hline$\$ 251,000-\$ 500,000$ & $32 \%$ & 17 \\
\hline Over $1,000,000$ & $35 \%$ & 19 \\
\hline \multicolumn{3}{|l|}{ Revenue Sources } \\
\hline Rent & $13 \%$ & 19 \\
\hline Fees from goods, services, or program fees & $17 \%$ & 30 \\
\hline Contracts & $9 \%$ & 12 \\
\hline Foundation grants & $9 \%$ & 18 \\
\hline Government grants & $22 \%$ & 26 \\
\hline Private donations & $6 \%$ & 23 \\
\hline Special events & $2 \%$ & 8 \\
\hline University support & $10 \%$ & 13 \\
\hline Other & $12 \%$ & 13 \\
\hline \multicolumn{3}{|l|}{ Policy Focus } \\
\hline Education & $13 \%$ & 17 \\
\hline Health & $12 \%$ & 16 \\
\hline Workforce Development & $12 \%$ & 16 \\
\hline Women's Issues & $11 \%$ & 14 \\
\hline Technology Development & $18 \%$ & 23 \\
\hline Criminal Justice & $3 \%$ & 4 \\
\hline Social Justice & $11 \%$ & 14 \\
\hline Children's Issues & $5 \%$ & 6 \\
\hline Other & $16 \%$ & 21 \\
\hline
\end{tabular}


Table 3. ANOVA Means Analysis of Key Incubator Descriptors

\begin{tabular}{lccccc}
\hline & Nonprofit Incubator & Other Sector Incubator & \\
\hline & Mean & $\begin{array}{c}\text { Std. } \\
\text { Deviation }\end{array}$ & Mean & $\begin{array}{c}\text { Std. } \\
\text { Deviation }\end{array}$ & Sig. \\
\hline Years of Operation & 21.5 & 16.0 & 11.7 & 10.3 & $\mathbf{. 0 0 2}$ \\
Budget & $6,063,604$ & $17,544,380$ & 600,355 & 833,957 & $\mathbf{. 0 0 2}$ \\
\# Full Time Employees & 29 & 91 & 4 & 6 & $\mathbf{. 0 6 9}$ \\
\# Part Time Employees & 12 & 45 & 2 & 3 & .135 \\
Years of Startup Program & 13 & 11 & 10 & 10 & .167 \\
\# Startup Participants & 45 & 57 & 132 & 440 & .532 \\
Revenue Diversity & 2.7 & 2.0 & 1.9 & 1.7 & $\mathbf{0 . 0 8 2}$ \\
\# Financial Services & 12 & 5 & 10 & 5 & 0.182 \\
\# Leadership Services & 16.7 & 6.1 & 13.4 & 7.9 & 0.108 \\
\# Communication Services & 16.1 & 3.9 & 12.5 & 6.9 & $\mathbf{0 . 0 3 4}$ \\
\# Legal Services & 6.1 & 1.9 & 5 & 2.5 & 0.101 \\
\hline
\end{tabular}


Table 4. Crosstab Analysis of Key Incubator Descriptors

\begin{tabular}{|c|c|c|c|c|c|}
\hline & & $\begin{array}{l}\text { Nonprofit } \\
\text { Incubator }\end{array}$ & $\begin{array}{c}\text { Other } \\
\text { Sector } \\
\text { Incubator }\end{array}$ & Total & Sig. \\
\hline \multirow{2}{*}{$\begin{array}{l}\text { Governance structure: Advisory } \\
\text { Board }\end{array}$} & Count & 7 & 10 & \multirow{2}{*}{98} & \multirow{2}{*}{.605} \\
\hline & $\%$ within & $20 \%$ & $16 \%$ & & \\
\hline \multirow{2}{*}{$\begin{array}{l}\text { Governance structure: Board of } \\
\text { Directors }\end{array}$} & Count & 29 & 3 & \multirow{2}{*}{98} & \multirow{2}{*}{.000} \\
\hline & \% within & $83 \%$ & $5 \%$ & & \\
\hline \multirow{2}{*}{ Governance structure: Consultant } & Count & 0 & 0 & \multirow{2}{*}{98} & \\
\hline & $\%$ within & $0 \%$ & $0 \%$ & & \\
\hline \multirow{2}{*}{$\begin{array}{l}\text { Governance structure: Management } \\
\text { Team }\end{array}$} & Count & 11 & 16 & \multirow{2}{*}{98} & \multirow{2}{*}{.522} \\
\hline & $\%$ within & $31 \%$ & $25 \%$ & & \\
\hline \multirow{2}{*}{$\begin{array}{l}\text { Governance structure: Steering } \\
\text { Committee }\end{array}$} & Count & 0 & 1 & \multirow{2}{*}{98} & \multirow{2}{*}{.454} \\
\hline & \% within & $0 \%$ & $2 \%$ & & \\
\hline \multirow{2}{*}{$\begin{array}{l}\text { Governance structure: University } \\
\text { Appointee }\end{array}$} & Count & 2 & 6 & \multirow{2}{*}{98} & \multirow{2}{*}{.509} \\
\hline & $\%$ within & $6 \%$ & $10 \%$ & & \\
\hline \multirow{2}{*}{ Governance structure: Other } & Count & 2 & 2 & \multirow{2}{*}{98} & \multirow{2}{*}{.543} \\
\hline & \% within & $6 \%$ & $3 \%$ & & \\
\hline \multirow{2}{*}{ Use of Volunteers } & Count & 22 & 16 & \multirow{2}{*}{98} & \multirow{2}{*}{.356} \\
\hline & $\%$ within & $63 \%$ & $52 \%$ & & \\
\hline \multirow{2}{*}{ Logic Model } & Count & 17 & 15 & \multirow{2}{*}{98} & \multirow{2}{*}{.817} \\
\hline & $\%$ within & $58 \%$ & $56 \%$ & & \\
\hline \multirow{2}{*}{ Network Member } & Count & 17 & 16 & \multirow{2}{*}{98} & \\
\hline & $\%$ within & $57 \%$ & $55 \%$ & & .908 \\
\hline & Count & 10 & 9 & & \\
\hline Startup Initiative: Incubator & $\%$ within & $29 \%$ & $14 \%$ & 98 & .087 \\
\hline & Count & 6 & 8 & & \\
\hline Startup Initiative: Accelerator & $\%$ within & $17 \%$ & $13 \%$ & 98 & .547 \\
\hline Startun Initiative. Coworking Snace & Count & 3 & 2 & & \\
\hline Startup Initiative: Co-working Space & \% within & $9 \%$ & $3 \%$ & 98 & .245 \\
\hline Startun Initiative. Other & Count & 13 & 11 & & \\
\hline Startup Initiative: Other & $\%$ within & $37 \%$ & $17 \%$ & 98 & .030 \\
\hline Geography of service: City & $\begin{array}{l}\text { Count } \\
\% \text { within }\end{array}$ & $\begin{array}{c}15 \\
43 \%\end{array}$ & $\begin{array}{c}18 \\
29 \%\end{array}$ & 98 & .152 \\
\hline Geography of service: County & $\begin{array}{l}\text { Count } \\
\% \text { within }\end{array}$ & $\begin{array}{c}16 \\
46 \%\end{array}$ & $\begin{array}{c}18 \\
29 \%\end{array}$ & 98 & .1088 \\
\hline Geography of service: State & Count & 19 & 17 & 98 & 007 \\
\hline Geography of service: State & $\%$ within & $54 \%$ & $27 \%$ & 98 & .007 \\
\hline & Count & 12 & 11 & 00 & \\
\hline Geography of service: Other & $\%$ within & $34 \%$ & $17 \%$ & 98 & .060 \\
\hline Policy focus: Education & $\begin{array}{l}\text { Count } \\
\% \text { within }\end{array}$ & $\begin{array}{c}11 \\
31 \%\end{array}$ & $\begin{array}{c}6 \\
10 \%\end{array}$ & 98 & .006 \\
\hline Policy focus: Health & $\begin{array}{l}\text { Count } \\
\% \text { within }\end{array}$ & $\begin{array}{c}10 \\
29 \%\end{array}$ & $\begin{array}{c}6 \\
10 \%\end{array}$ & 98 & .015 \\
\hline
\end{tabular}


Policy focus: Workforce development

Policy focus: Women's issues

Policy focus: Technology development

Policy focus: Criminal justice

Policy focus: Social justice

Policy focus: Children's issues

Policy focus: Other

Reasons for creation: Lack of government services

Reasons for creation: Lack of market presence

Reasons for creation: New ordinance, regulation, policy Reasons for creation: Availability of financial resources

Reasons for creation: Community demand or need

Reasons for creation: Individual community champion

Reasons for creation: Other

\begin{tabular}{|c|c|c|c|c|}
\hline $\begin{array}{c}\text { Count } \\
\% \text { within }\end{array}$ & $\begin{array}{c}12 \\
34 \%\end{array}$ & $\begin{array}{c}4 \\
6 \%\end{array}$ & 98 & .000 \\
\hline $\begin{array}{c}\text { Count } \\
\% \text { within }\end{array}$ & $\begin{array}{c}9 \\
26 \% \\
\end{array}$ & $\begin{array}{c}5 \\
8 \% \\
\end{array}$ & 98 & .016 \\
\hline $\begin{array}{c}\text { Count } \\
\% \text { within }\end{array}$ & $\begin{array}{c}11 \\
31 \% \\
\end{array}$ & $\begin{array}{c}12 \\
19 \%\end{array}$ & 98 & .166 \\
\hline $\begin{array}{c}\text { Count } \\
\% \text { within }\end{array}$ & $\begin{array}{c}3 \\
9 \% \\
\end{array}$ & $\begin{array}{c}1 \\
2 \% \\
\end{array}$ & 98 & .094 \\
\hline $\begin{array}{c}\text { Count } \\
\% \text { within }\end{array}$ & $\begin{array}{c}10 \\
29 \% \\
\end{array}$ & $\begin{array}{c}4 \\
6 \% \\
\end{array}$ & 98 & .003 \\
\hline $\begin{array}{c}\text { Count } \\
\% \text { within }\end{array}$ & $\begin{array}{c}5 \\
14 \% \\
\end{array}$ & $\begin{array}{c}1 \\
2 \% \\
\end{array}$ & 98 & .012 \\
\hline $\begin{array}{c}\text { Count } \\
\% \text { within }\end{array}$ & $\begin{array}{c}13 \\
37 \% \\
\end{array}$ & $\begin{array}{c}8 \\
17 \%\end{array}$ & 98 & .005 \\
\hline $\begin{array}{c}\text { Count } \\
\% \text { within }\end{array}$ & $\begin{array}{c}3 \\
9 \%\end{array}$ & $\begin{array}{c}3 \\
5 \%\end{array}$ & 98 & .451 \\
\hline $\begin{array}{c}\text { Count } \\
\% \text { within }\end{array}$ & $\begin{array}{c}5 \\
14 \%\end{array}$ & $\begin{array}{c}9 \\
14 \%\end{array}$ & 98 & 1.00 \\
\hline $\begin{array}{c}\text { Count } \\
\% \text { within }\end{array}$ & $\begin{array}{c}1 \\
3 \%\end{array}$ & $\begin{array}{c}2 \\
3 \%\end{array}$ & 98 & .930 \\
\hline $\begin{array}{c}\text { Count } \\
\% \text { within }\end{array}$ & $\begin{array}{c}4 \\
11 \% \\
\end{array}$ & $\begin{array}{c}3 \\
5 \%\end{array}$ & 98 & .219 \\
\hline $\begin{array}{c}\text { Count } \\
\% \text { within }\end{array}$ & $\begin{array}{c}20 \\
57 \%\end{array}$ & $\begin{array}{c}17 \\
27 \%\end{array}$ & 98 & .003 \\
\hline $\begin{array}{c}\text { Count } \\
\% \text { within }\end{array}$ & $\begin{array}{c}7 \\
20 \% \\
\end{array}$ & $\begin{array}{c}7 \\
11 \%\end{array}$ & 98 & .228 \\
\hline $\begin{array}{c}\text { Count } \\
\% \text { within }\end{array}$ & $\begin{array}{c}6 \\
17 \%\end{array}$ & $\begin{array}{c}5 \\
8 \%\end{array}$ & 98 & .167 \\
\hline
\end{tabular}

